PRZEGLĄD RUSYCYSTYCZNY 2021, nr 4 (176)

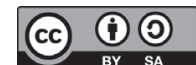

DOI 10.31261/pr.11952

\title{
MICHAEL KUHN
}

Uniwersytet Jagielloński w Krakowie

iD https://orcid.org/0000-0001-6258-4740

KATARZYNA JAWOR

Uniwersytet Jagielloński w Krakowie

iD https://orcid.org/0000-0002-9947-3718

\section{ТИПОЛОГИЯ ОБРАЗОВ ФРОНТОВИЧЕК В ФИЛЬМЕ ДЫЛДА КАНТЕМИРА БАЛАГОВА}

THE TYPOLOGY OF FEMALE FRONT-LINE SOLDIERS IMAGES IN BEANPOLE FILM BY KANTEMIR BALAGOV

In this article with the use of descriptive-functional and comparative research methods are analyzed and compared with each other the two main characters of the movie Beanpole (2019) by Russian director Kantemir Balagov — young female front-line soldiers lya and Masha, who are trying to start a peaceful life in post-blockade Leningrad. The image of each heroine is scrutinized through separate categories from the perspective of anthropology and psychology - Appearance, Clothing, Character, Love, Children, Trauma, War and peaceful life. The comparison of completely different yet very close friends allows one to find a parallel in the concept of Chinese philosophy yin and yang and subject the characters to the first such typology in the scientific literature. Besides, the analysis helps to draw some conclusions regarding the present and future of the heroines: post-war life sometimes appears to be more difficult to front-line soldiers than the military one.

Keywords: Kantemir Balagov, Beanpole, contemporary Russian cinema, female image in cinema, female front-line soldier image, World War II, post-war period, anthropology, psychology, psychic trauma, physical trauma, yin and yang, color dramaturgy

\section{ВСТУПЛЕНИЕ}

Вслед за мировой тенденцией в российском кинематографе в течение прошедшего десятилетия наблюдалось повышение интереса к еще до недавнего времени ощутимо обделенной вниманием теме - раскрытию амбивалентных женских персонажей. К 2020 году можно выделить нескольких режиссеров, в чьих фильмографиях основным предметом исследования являлись 
женские образы, причем не только в рамках авторского кино, но и фильмов рассчитанных на широкую аудиторию. Находится здесь место как, что вполне ожидаемо, режиссерам-женщинам ${ }^{1}$, так и, что представляет собой особую ценность в по-прежнему преимущественно мужском мире российского кинематографа, режиссерам-мужчинам ${ }^{2}$. Показательно, что события подавляющей части кинокартин с героинями, находящимися в центре сюжета, разворачиваются в современности. В свою очередь, например, среди регулярных в последние годы обращений кинематографистов России к боевым действиям времен Второй мировой войны, в которой по статистике приняло участие самое большое число женщин за всю историю ${ }^{3}$, феминная оптика применяется заметно реже4. Первые послевоенные годы, показанные с перспективы возвратившихся домой фронтовичек, представляют же собой исключительный дефицит 5 .

Одним из знаковых российских фильмов 2019 года несомненно стала авторская антивоенная драма Дылда режиссера Кантемира Балагова, повествующая о двух фронтовых подругах, пытающихся вернуться к мирной жизни в Ленинграде конца 1945 - начала 1946 годов $^{6}$. Выпускник мастерской

${ }^{1}$ Примеры: Кококо (2012) Авдотьи Смирновой, Как меня зовут (2014) и Верность (2019) Нигины Сайфуллаевой, Давай разведемся! (2019) Анны Пармас, Любовницы (2019) и Один вдох (2020) Елены Хазановой, Доктор Лиза (2020) Оксаны Карас и др.

2 Примеры: Елена (2011) Андрея Звягинцева, Батальонъ (2014) Дмитрия Месхиева, Жги! (2017) и Без меня (2018) Кирилла Плетнева, Я худею (2018) Алексея Нужного, На острие (2020) Эдуарда Бордукова и др.

3 Так, к примеру, согласно официальным данным в период с 1941 по 1945 годы в СССР на военную службу было призвано 490235 женщин. Подробнее см.: М. Елисеева, Сила слабых: женщины на Великой Отечественной войне, https://army.ric.mil.ru/Stati/item/252043/ (10.05.2021); С.А. Алексиевич, У войны не женское лицо, Время, Москва 2019, с. 5-6.

4 Два, пожалуй, самых известных примера последнего десятилетия: Битва за Севастополь (2015) Сергея Мокрицкого и А зори здесь тихие... (2015) Рената Давлетьярова.

5 См.: А. Артамонов, Кантемир Балагов: «Надо взять зрителя за шкирку и не отпускать его», https://seance.ru/articles/dylda-balagov-interview/ (10.05.2021).

${ }^{6}$ Cм.: H. Chu, Oscar-shortlisted 'Beanpole' is a solid, if bleak, sophomore effort by Kantemir Balagov, https://www.washingtonpost.com/goingoutguide/movies/oscar-shortlisted-beanpole-is-a-solid-if-bleak-sophomore-effort-by-kantemir-balagov/2020/02/18/2c398efe-4ea5-11ea-bf44-f5043eb3918a_story. html?arc404=true (10.05.2021). 
Александра Сокурова, родившийся 28 июля 1991 года и проведший значительную часть жизни в традиционно ассоциирующейся со строгой патриархальной системой Кабардино-Балкарской Республике, в своих интервью решительно заявляет: «[...] герой нашего времени - женщина»8. Выбор темы для второй полнометражной работы, над сценарием ${ }^{9}$ которой Балагов трудился вместе с писателем Александром Тереховым, режиссер объясняет так:

Для меня война неприемлема, это смещение человеческой природы. Особенно в случае женщины, которая по своей природе биологической должна давать жизнь. В течение нескольких лет она просто окружена смертью - насколько это влияет на ее физику, ее биологию, психологию? Об этом я хотел снять фильм ${ }^{10}$.

Незаурядные и противоречивые женские образы являются отличительной чертой фильмографии молодого и уже сейчас невероятно успешного российского режиссера. Полнометражный дебют уроженца Нальчика - семейная драма Теснота (2017) рассказывает об удушливых для еврейской девушки национальных традициях Северного Кавказа конца 1990-х годов. Он был удостоен приза жюри кинокритиков и киноведов ФИПРЕССИ в программе Особый взгляд на Каннском кинофестивале 2017 года ${ }^{11}$. Драму Дылда, вдохновленную художественно-документальной книгой лауреата Нобелевской премии по литературе Светланы Алексиевич У войны не женское лищо, по сравнению с Теснотой, ожидал еще более громкий фестивальный успех. На 72-м Каннском кинофестивале Балагову удалось не только

7 См.: А. Артамонов, Кантемир Балагов: «Надо взять зрителя..., https:// seance.ru/articles/dylda-balagov-interview/ (10.05.2021).

${ }^{8}$ А. Иванов, Кантемир Балагов: «Я не особенный, мне просто пока везет, вот u все», https://bazaar.ru/bazaar-art/kino/kantemir-balagov-ya-ne-osobennyymne-prosto-poka-vezet-vot-i-vse/ (10.05.2021).

${ }^{9}$ Авторы статьи выражают благодарность продюсеру фильма Дылда Александру Роднянскому за любезно предоставленную режиссерскую версию сценария.

${ }^{10}$ А. Долин, «Мы не имеем права показывать своих героев слабыми, мы должны уважать их личность». Режиссер Кантемир Балагов - о фильме «Дылда», дважды награжденном в Каннах, https://meduza.io/feature/2019/o6/19/ my-ne-imeem-prava-pokazyvat-svoih-geroev-slabymi-my-dolzhny-uvazhat-ihlichnost (10.05.2021).

${ }^{11}$ См.: А. Исрапилов, Рецензия на фильм «Дылда»: Ленинград, открытый гоpod, https://www.film.ru/articles/recenziya-na-film-dylda (10.05.2021). 
повторить свое же достижение двухлетней давности ${ }^{12}$ и получить награду от Международной федерации кинопрессы за лучшую режиссуру, но также и вместе со своим фильмом заслужить почетное право быть выдвинутым от России на премию Оскар в номинации лучший иностранный художественный фильм ${ }^{13}$.

Обращаясь к описательно-функциональному и сравнительно-сопоставительному методам, авторы статьи ставят перед собой задачу рассмотреть и проанализировать изображенные в фильме Дьлда образы главных героинь - фронтовичек Ии (Виктория Мирошниченко) и Маши (Василиса Перелыгина) с перспективы антропологии и психологии. Их частная история представляет собой иллюстрацию того, что после победы 1945 года пережили сотни тысяч советских женщин, ушедших на фронт. О судьбе девушек до показанных в фильме событий (осени 1945 - зимы 1946 годов) достоверно почти ничего неизвестно. В наличии лишь некоторые, порой взаимоисключающие фрагменты из их биографий ${ }^{14}$. Описательно-функциональный метод применяется для превращения многоуровневого аудиовизуального текста с продуманной цветовой драматургией ${ }^{15}$ в сжатый вербальный текст, а сравнительно-сопоставительный метод используется для установления схожести и различий двух героинь. Образы молодых фронтовичек изучены в рамках следующих тематических категорий: Внешний вид, Одежда, Характер, Любовь, Дети, Травма, Война и мирная жизнъ. Полученные результаты подвергнуты оригинальной типологии, базирующейся на концепции из китайской философии.

\section{КОНЦЕПЦИЯ}

Инъ и ян обозначает соединение двух противоположностей (например, черное и белое, женское и мужское, пассивное и активное),

${ }^{12}$ Вторая полнометражная работа Балагова тоже была удостоена приза ФИПРЕССИ, что является беспрецедентным случаем в истории Каннского кинофестиваля.

${ }^{13}$ Cм.: H. Chu, Oscar-shortlisted 'Beanpole'...

${ }^{14}$ См.: Е. Смолина, «Дылда» Кантемира Балагова в "Особом взгляде» Каннского фестиваля, https://www.gq.ru/entertainment/dylda-review (10.05.2021).

${ }_{15}$ См.: А. Долин, "Дылда» Кантемира Балагова: сильная история любви в послеблокадном Ленинграде, https://meduza.io/feature/2019/o5/16/dyldakantemira-balagova-istoriya-lyubvi-v-posleblokadnom-leningrade (10.05.2021). 
чье взаимодействие и взаимодополнение приводит к обретению устойчивого биполярного мира. Широко известный символ изображается в виде круга (Дао), разделенного на две половины (одной черной $-u н ь$, другой белой $-я н$ ) линией, своими контурами напоминающей латинскую букву $s$. Извилистая граница между половинами указывает на движение, с которым инь и ян устремлены друг к другу. Преодоление ими бинарной оппозиции и дифференциации приводит к гармонии и равенству. В каждой половине имеется по одному маленькому кругу окрашенного в противоположный цвет, что указывает не только на антитезу и взаимодополнение оппозиций, но и на их ответственность за производство друг друга. Нарушение единого целого, баланса между полярными силами, рискует обернуться катастрофой ${ }^{16}$.

Согласно ряду интервью, опираясь на данную концепцию режиссер Дылды выстраивал модель отношений между главными героинями ${ }^{17}$. Степень соответствия пары Ия и Маша пребывающим в гармонии инь и ян будет установлена в заключительной части статьи.

\section{ВНЕШНИЙ ВИД}

Великанше Ие около 23-24 лет. Худая девушка обладает несвойственной для своего гендера физической силой. Она может серьезно покалечить незнакомых юношей, а затем на себе вытащить раненую подругу с «поля боя». Ее голос совсем не соответствует голосу молодой девушки; по своему звучанию он скорее напоминает старый, заржавевший механизм. Из-за светлого цвета волос, бровей и ресниц Ия похожа на альбиноса с буро-желто-зелеными глазами ${ }^{18}$. На бледном, лишенном эмоций лице иногда возникает застенчивая улыбка. Появляющиеся при этом ямочки на щеках придают ему детскость. У героини поте-

${ }^{16}$ Cм.: R. L. Taylor, H.Y.F. Choy, Yin/yang // они же, The Illustrated Encyclopedia of Confucianism, Vol. 2, The Rosen Publishing Group, Inc., New York 2005, c. $719-722$.

${ }^{17}$ Cм.: C. Aguilar, "War Is a Source of Human Nature": Kantemir Balagov on His Women-Centered Period Two-Hander, Beanpole, https://filmmakermagazine. com/109227-war-is-a-source-of-human-nature-kantemir-balagov-on-his-women-centered-period-two-hander-beanpole/\#.Xq_NH5ngo2x (10.05.2021).

${ }^{18}$ Cм.: D. Polok, Wojna psychologiczna (Wysoka dziewczyna), http://artpapier. com/index.php?page $=$ artykul\&wydanie $=381 \&$ artykul=7588 (11.05.2021). 
рянный, доверчивый взгляд, она редко мигает. Вследствие чего Ия видится опаленным фронтовым зноем цветком, с молчаливым горем взирающим на разрушенный послевоенный мир ${ }^{19}$.

Несмотря на свой юный возраст (после демобилизации героине примерно 23 года), физически и психологически Маша ощущает себя заметно старше сверстников, не принимавших участия в военных действиях. На фоне Ии, рыжеволосая, коротко подстриженная героиня выглядит маленькой, субтильной девушкой, почти подростком. От Маши так и веет опасностью: у нее низкий голос с хрипотцой, плотоядная улыбка и болезненный блеск в глазах. Выражение ее веснушчатого лица с ямочкой на подбородке крайне переменчиво. Веселый задор может мгновенно смениться беспокойным поигрыванием скулами, громким сглатыванием и испытующим взглядом темно-карих глаз. B ее энергичной жестикуляции улавливается напряженность, готовность атаковать. Не обладая внушительной физической силой Маша может легко причинить окружающим боль, например, удерживая фронтовую подругу в удушливых объятиях, или разбивая ей нос, либо же оглушить резким движением, например, выпрыснув застенчивому юноше в лицо коньяк.

\section{ОДЕЖДА}

Несмотря на то, что Ия была на фронте, в постблокадном Ленинграде она почти не надевает военной формы. Только ближе к концу фильма фронтовичка появляется в солдатской шинели. Ия одевается многослойно. В течение практически всей кинокартины героиня одета в один и тот же зеленый свитер в охровую полоску, из-под которого выглядывают рукава и воротничок зеленой рубашки в черный горошек, а также в длинную темно-зеленую юбку. Верхняя одежда девушки невзрачна: клетчатое пальто, вязаная шапка с длинными ушами, высокие валенки. Ее будничный гардероб подчеркивает неуклюжесть, безличность героини. В такой одежде молодая фронтовичка напоминает быстро растущего ребенка, не замечающего того, что из своего привычного гардероба он уже давно вырос. В военном госпитале, где Ия работает медсестрой, она носит медицинскую

${ }^{19}$ В переводе с греческого имя героини означает «фиалка», см.: А.В. Суперанская, Современный словарь личных имен: Сравнение. Происхождение. Написание, Айрис-пресс, Москва 2005, с. 294. 
форму - белый халат ей слишком мал, завязанные в пучок волосы скрывает белая косынка. Зеленый цвет доминирует в гардеробе девушки и в окружающей ее обстановке. Данный цвет символизирует в фильме Балагова плодородие, жизнь, надежду $^{20}$. Он соответствует ее спокойному характеру и подчеркивает довольно длительное присутствие фронтовички в мирной реальности ${ }^{21}$. Однако зеленый не единственный цвет в послевоенной жизни героини. В окружающей ее обстановке уже с самого начала фильма присутствуют красные и охровые элементы. Сперва незаметные, они (в особенности красный) после возвращения Маши с фронта все ощутимее присутствуют в жизни девушки. Красный цвет становится более отчетливым в гардеробе фронтовички после процедуры насильственного зачатия - героиня сидит на кровати, впервые одетая в зеленый кардиган с двумя вертикальными красными полосами и охровым орнаментом. Тот же кардиган Ия продолжает носить и в последующих сценах. Одежду девушки полностью пронизывает кроваво-красный в финале фильма, когда она сама надевает подаренный Машей однотонный красный свитер (возможно военный трофей).

Осенью 1945 года Маша буквально ураганным ветром врывается в тихую ленинградскую коммунальную квартиру. Первоначально ее гардероб сугубо мужской, военный: шапка-ушанка, солдатская шинель, гимнастерка с боевыми наградами, армейский ремень, брюки, кирзовые сапоги. Армейская жизнь приучила молодую фронтовичку к строевой выправке. С собой Маша привозит компактный трофейный чемодан, содержимое которого указывает на тоску девушки по мирному времени и надежду на обретение простого женского счастья - замужество и материнство. Он вмещает в себя ряд фундаментальных, не связанных с войной предметов: одежда (свитеры, женский нижний трикотаж), косметика, спиртное, сладости, детская игрушка. Вновь обрести свою женственность посредством мирной одежды ей только предстоит ${ }^{22}$. В госпитале героиня надевает косынку

${ }^{20}$ См.: И. Домбровская, «Траурное соседство с жизнъю» - Кантемир Балагов о своем фильме «Дылда», http://www.rfi.fr/ru/kultura/20190516-kantemirbalagov-cheloveku-nuzhen-chelovek (11.05.2021).

${ }^{21}$ См.: А. Исрапилов, Рецензия на фильм..., https://www.film.ru/articles/recenziya-na-film-dylda (11.05.2021).

${ }^{22}$ Cм.: J. Tangcay, How Research Prompted 'Beanpole' Director Kantemir Balagov to Shoot in Color, https://variety.com/2020/artisans/awards/beanpole-kantemir-balagov-1203456481/ (11.05.2021). 
и мешковатый медицинский халат, из-под которого неизменно выглядывает воротничок красной рубашки с зелеными узорами. Первенствующим цветом в ее будничной одежде является красный: цвет войны, смерти и крови ${ }^{23}$. Постепенно, словно молодая трава, через него «прорастает» зеленый. Сначала поверх красной рубашки с вкраплением зеленого Маша, практически всегда, носит темно-зеленую жилетку. Позднее в ее повседневном гардеробе все чаще оказывается причудливо-разноцветная кофта: преимущественно красный низ противостоит зеленому верху, а отделяет их охровая граница. В однотонной одежде в вязаном свитере цвета охры («цвет ржавчины» $\left.{ }^{24}\right)-$ фронтовичка появляется единожды и на короткое время, пока сушится ее повседневная одежда. Девушке случайно доводится примерить чужое летнее платье зеленого цвета, в которое вкраплены красные пятна в виде цветов. Платье оказывается ей впору. При кружении в нем Маша испытывает целый спектр эмоций: первичная неловкость сменяется радостью, затем наступают секунды внезапной тревоги, чтобы в конце взорваться яростным исступлением. Предназначенное для другой нарядное платье дало ей острое осознание того, что ее юность была «убита» на войне и ее невозможно выпросить взаймы ${ }^{25}$. Зеленый же цвет, к которому Маша изо всех сил стремится, никогда не станет монохромным. Он всегда будет испещрен красными пятнами, как напоминание о войне и иллюзорности многообещающего будущего.

\section{XAPAKTEP}

Ия немногословна, редко делится своими мыслями. Героиня не привыкла самостоятельно принимать решения. Она доверчива и легко подвергается манипуляциям. У нее развито чувство эмпатии, чем активно пользуются другие персонажи фильма. При этом девушка добровольно вступает в отношения, при

${ }^{23}$ См.: В. Чугункина, Как самородок из Нальчика Кантемир Балагов стал надеждой российского кинематографа, https://ru.hellomagazine.com/zvezdy/ intervyu-i-video/31961-kak-samorodok-iz-nalchika-kantemir-balagov-stalnadezhdoy-rossiyskogo-kinematografa.html (11.05.2021).

${ }^{24}$ И. Домбровская, «Траурное соседство..., http://www.rfi.fr/ru/kultura/20190516-kantemir-balagov-cheloveku-nuzhen-chelovek (11.05.2021).

${ }_{25}$ Cм.: J. Tangcay, How Research..., https://variety.com/2020/artisans/awards/ beanpole-kantemir-balagov-1203456481/ (11.05.2021). 
которых она лишена права голоса. Помощь Ии бескорыстна и милосердна. Она пытается дать надежду на исцеление неизлечимо больному инвалиду в госпитале, с материнской любовью растит маленького сына фронтовой подруги. В ее поведении и способе мышления много инфантилизма. Язык героини специфический. Она пользуется простыми, зачастую грамматически неверными формулировками. Этот корявый, наивный язык, отсылает зрителя к манере речи литературных героев Андрея Платонова ${ }^{26}$. В ключевые моменты, как например, во время откровенного разговора с Машей, специфический язык фронтовички внезапно обретает многозначность и помогает ей в лаконичной форме высказать о себе главное. «Я напрасная внутри» (2:07:15- 2:07:19), - признается Ия подруге. Данная реплика содержит в себе не только признание в отсутствии беременности, но и раскаяние в своей душевной отстраненности и потерянности.

По психическому складу Машу следует отнести к экстраверту, искалеченному жуткими потрясениями. На первый взгляд она представляется провокационно жизнерадостной, смешливой, высоко эмоциональной плутовкой, необъяснимой волей случая оказавшейся в изможденном блокадой городе. Довольно быстро становится понятно, что ее жизнерадостность - дешевый фасад, с переменным успехом прикрывающий глубокие физические и психологические травмы. В ее беспрестанной улыбке и громком смехе на самом деле преобладают ноты безумия. Чрезмерная эмоциональность возникает лишь короткими вспышками, поскольку на постоянство фронтовичке попросту не хватает сил ${ }^{27}$. Таким образом, пассионарий Маша выявляет себя как амбивалентный персонаж, в значительной мере несущий с собой разрушение, чем созидание. Она жестокий манипулятор, привыкший подчинять окружающих своей воле. Она коварная интриганка, пребывающая вне рамок морали и незнающая чувства эмпатии. Вместе с тем она же, может предстать в образах тактильной, верной подруги и непутевой, но заботливой матери. Внутри нее не прекращается война. Ее волевой характер герояпобедителя пребывает в непрерывном конфликте с уязвимым сердцем слишком рано повзрослевшей девушки.

${ }^{26}$ См.: А. Артамонов, Кантемир Балагов: «Надо взять зрителя..., https:// seance.ru/articles/dylda-balagov-interview/ (10.05.2021).

${ }^{27}$ Cм.: J. Kiang, Film Review: 'Beanpole', https://variety.com/2019/film/marketsfestivals/beanpole-review-1203215728/ (11.05.2021). 


\section{люБОвь}

У Ии нет ни семьи, ни возлюбленного. Нет у нее даже желания создать семью, выйти замуж, родить детей. Между тем молодая медсестра находится в хороших отношениях с солдатами - общий военный опыт облегчает им взаимопонимание. Ия обходится с ними по-дружески, шутит как с братьями. С заботой и искренней симпатией она ухаживает за парализованным «снайпером-героем» (04:05-04:07) Степаном (Константин Балакирев). К начальнику отделения госпиталя Николаю Ивановичу (Андрей Быков) героиня испытывает доверие, хотя и чувствует себя в его присутствии скованно, как при строгом отце. Молодая фронтовичка не готова вступать с мужчинами в отношения иного рода - она испытывает непреодолимый страх перед интимной близостью. Секс является для Ии травмирующим, принудительным действием, направленным единственно на то, чтобы забеременеть ${ }^{28}$.

Отношение героини к Саше (Игорь Широков), ухажеру Маши, изначально враждебное. Она не понимает зачем подруге нужно его присутствие в их жизни, борется с юношей за благосклонность Маши и боится, что та может ее оставить. Девушка стремится удержать фронтовую подругу при себе. Ия сочувствует Маше, когда та истерически крутится в зеленом платье. Пытаясь ее утешить она инициирует поцелуи, которые быстро перерастают в борьбу между девушками. Это спонтанное проявление физической силы указывает на неоднозначное отношение Ии к Маше ${ }^{29}$. Беременность для героини представляет собой возможность приобрести власть над своевольной подругой, в чем она сама признается намеченному отцу: «Хочу стать ей хозяйкой» (1:44:55-1:45:00). Вместе с тем Ия чувствует страх перед Машей, волнуется ожидая ее реакции на ложь и отсутствие беременности. Девушка даже предпринимает попытку убежать от опасной подруги. Тем не менее, как бы сильно Маша не притесняла Ию, та не может без нее жить, поскольку связана с ней общей военной судьбой, травмой и одиночеством уже навсегда.

Для Маши война с нацистской Германией знаменательна встречей с любимым мужчиной. Вероятно именно на фронте, до

${ }^{28}$ Cм.: H. Chu, Oscar-shortlisted 'Beanpole'...

${ }^{29}$ См.: Н. Карцев, Пустота. «Дылда», режиссер Кантемир Балагов, «Искусство кино» 2019. № 7/8, с. 189-190. 
гибели возлюбленного, она ощущала себя по-настоящему счастливой. Домой фронтовичка возвращается совершенно измученным, искалеченным, постаревшим душой и телом одиноким человеком. Несмотря на это героиня не перестает мечтать и надеется на обретение любви. Решившись во что бы то ни стало вновь стать матерью, Маша начинает оценивать мужчин исключительно как особей, способных справиться с ролью биологического отца. Как раз за этим она поздним вечером и отправляется в ленинградский дом культуры на танцы, место должное, в ее представлении, стать идеальным для мимолетной интимной связи. Закрытые двери развлекательного учреждения не выглядят серьезной преградой для решительной фронтовички. Определившись с «целями» (юный Саша и его друг (Вениамин Кац)), она сразу по ним «стреляет» (отвечает на их заурядный флирт). Без долгой прелюдии Маша сама тащит неопытного Сашу на заднее сидение автомобиля, чтобы лишить его девственности ${ }^{30}$. На тот момент наивный подросток не рассматривается ею как любовник на длительный срок. Героине нужен результат (зачатие) здесь и сейчас, а на месте Саши мог оказаться любой другой незнакомец. С той же целью позднее был выбран и Николай Иванович. В качестве биологического отца будущего ребенка Маша выбирает его не из личной симпатии, а из-за его репродуктивного возраста и наличия на него компромата. Неумелые ухаживания влюбленного Саши сперва забавляют девушку. Она его не отвергает, потому что через него, сына из влиятельной номенклатурной семьи, решает наладить снабжение продуктами будущую мать их ребенка (Ию). Принимая Сашино предложение познакомится с его родителями, Маша надеется на создание «нормальной семьи» (1:59:22-1:59:24).

Совсем по-иному выстроены отношения с Ией. Изначально она относится к фронтовой подруге как к послушному ребенку, которым легко командовать. Маша ей доверяет, но вместе с тем понимает, что они с ней порочно близки. С одной стороны, им мучительно тяжело вместе; с другой - они не могут существовать отдельно друг от друга. Их первоначальные отношения родитель (Маша)/ребенок (Ия) в постблокадном Ленинграде резко преобразуются в пару похититель (Маша)/заложник (Ия), чтобы затем незаметно мутировать в отношения супруг (Маша)/

${ }^{30}$ См.: H. Chu, Oscar-shortlisted 'Beanpole’... 
супруга (Ия). Для создания некого подобия семьи из двух изуродованных (прежде всего, внутренне), страстно желающих разъединиться и вместе с тем накрепко припаянных друг к другу неприкаянных душ, требуется устремление к общей цели-чуду (совместный ребенок как исцеление), о чем Маша опускаясь на колени и просит Ию в заключительной сцене фильма:

Дай мне руку. Я только с вами рядом теперь. Мне не нужен никто. И Саши не будет никогда. Ты родишь... И обязательно вырастет мальчишка. Мы его воспитаем, потом я, потом я пойду учиться. Мы будем ходить в кино и... Он вырастет умным. Глаза будут твои, нос - мой. Высокий. Он нас вылечит... (2:10:10-2:11:52).

\section{ДЕтИ}

Ия самостоятельно растит рыжеволосого малыша Пашку (Тимофей Глазков), сына Маши, которого окружающие воспринимают как ее ребенка. В его присутствии героиня свободно улыбается; он дарит ей мгновения счастья. Дополнительную ответственность за судьбу ребенка Ия испытывает ввиду его внешнего сходства с фронтовой подругой. С момента трагической гибели малыша, задохнувшегося в объятиях застывшей в очередном неконтролируемом ступоре фронтовички, ее преследует огромное чувство вины перед матерью Пашки. Героиня переживает изза его смерти, сочувствует подруге, но не понимает стремления Маши как можно скорее родить нового сына ${ }^{31}$. Если на протяжении почти всей кинокартины рождение ребенка сопряженно для Ии с унизительной процедурой зачатия и шансом удержать при себе близкого человека, то в финале, после убеждений Маши, оно уже видится ей чудодейственным эликсиром и мощным стимулом для продолжения жизни в послевоенной эпохе.

В период военных действий настоящая мать рыжеволосого малыша посчитала для себя важнее отомстить за гибель возлюбленного (отца Пашки), чем комиссоваться из армии и растить сына. Машино участие в жизни сына ограничивалось посылками с продуктами. Осенью 1945 года фронтовичка привозит для него игрушку символизирующую мир - плюшевую собачку.

${ }^{31}$ См.: F. Lévesque, «Une grande fille»: les amitiés contraires, https://www. ledevoir.com/culture/cinema/573381/une-grande-fille-les-amities-contraires (11.05.2021). 
Очевидно, что Пашка олицетворяет для девушки, с одной стороны, мучительное воспоминание о смертоносной войне (в частности о погибшем возлюбленном); с другой - спасательный круг в послевоенном море. Известие о гибели малыша вызывает у Маши неожиданную реакцию. Она с внешним спокойствием принимает весть об утрате сына и тут же предпринимает решительные действия для зачатия нового ребенка. Собственная бесплодность не останавливает ее от задуманного. Об усыновлении сироты она и слышать ничего не желает ${ }^{32}$. Послевоенный ребенок, вероятно, видится ей даже более предпочтительным вариантом, чем Пашка, поскольку он точно будет лишен красок смерти и поможет ей, униженной войной молодой женщине, начать жизнь с чистого листа.

\section{TPABMA}

После фронта у Ии остался шрам за правым ухом - единственное заметное физическое увечье. Полученная на войне контузия значительно повлияла на жизнь девушки. Травма головного мозга напоминает о себе посредством регулярных замираний героини на неопределенное время именно в те моменты, когда девушка испытывает сильные эмоции ${ }^{33}$. Война замедлила или даже остановила процесс психического развития девушки и та так и осталась на уровне простодушного подростка. Вместе с тем на фронте Ия не утратила нравственных ценностей. Она и в Ленинграде продолжает испытывать угрызения совести из-за безнравственных поступков, таких как шантаж начальника отделения госпиталя и утаивание правды от подруги.

Война сильно подорвала физическое и психическое здоровье Маши. Серия хирургических вмешательств лишила ее репродуктивной функции. С ней случаются болезненные приступы и носовые кровотечения, иногда с потерей сознания. Помимо этого война отобрала у Маши какое-либо представление о нравственных нормах, развила в ней эмоциональную нестабильность, приучила к частым потерям близких. Превратившись на фронте в монструозную эгоистку, девушка и в мирное время продолжает

${ }^{32}$ См.: Н. Карцев, Пустота..., с. 187-188.

${ }^{33}$ Cм.: D. Polok, Wojna psychologiczna..., http://artpapier.com/index.php?page$=$ artykul\&wydanie $=381 \&$ artykul=7588 (11.05.2021). 
упорно добиваться своего, готовая платить за достижение желаемого результата любую цену. Предположительно Маша страдает боевым посттравматическим стрессовым расстройством:

Это и психическая, и физическая, и моральная травма; это травма, затрагивающая и личностно-психологические основы индивида, и его социальную и биологическую сущность. Боевая психическая травма (БПТ) не ограничивается пределами театра военных действий, так как манифестация ее клинических проявлений нередко происходит спустя месяцы и даже годы после возвращения ветеранов к мирной жизни ${ }^{34}$.

\section{ВОЙНА И МИРНАЯ ЖИЗНЬ}

Чтобы добиться участия в боевых действиях, советским девушкам следовало пройти строгий отбор, а затем успешно окончить ускоренные курсы военной подготовки. Чувство патриотизма и стремление внести свой вклад в защиту родины помогали им пережить суровый армейский быт, который уже сам по себе для них был сравним с подвигом ${ }^{35}$. Такой путь проделала и Ия. Воевать против нацистской Германии героиня пошла, будучи еще по сути подростком. Она служила в зенитных войсках ${ }^{36}$. В победном мае 1945 года война для девушки не закончилась. В ленинградском госпитале Ия продолжает регулярно иметь дело со смертью, как в качестве пассивной наблюдательницы, так и ее вынужденной посланницы. Под давлением со стороны начальника отделения фронтовичка неоднократно выполняет незаконную процедуру эвтаназии. Когда Николай Иванович при соблюдении конфиденциальности передает Ие в ординаторской ампулу для убийства парализованного Степана («Это Степану. Надо ему помочь.» (1:02:58-1:03:03)), за девушкой на стене висит плакат с изображением улыбающегося советского солдата и лозунгом: «Ты вернул нам жизнь!». В тот момент, когда она

${ }^{34}$ С. Г. Сукиасян, В.А. Солдаткин, Е. В. Снедков, М.Я. Тадевосян, В. Г. Косенко, Боевое посттравматическое стрессовое расстройство: эволюция понятия от «синдрома раздраженного сердиа» до «психогенно-органического расстройства», «Журнал неврологии и психиатрии им. С.С. Корсакова» 2019, т. 119, № 6, с. 145.

${ }^{35}$ См.: С.А. Алексиевич, У войны..., с. 39-44.

${ }^{36}$ О фронтовом прошлом Ии становится известно из разговора Маши с Николаем Ивановичем. 
пытается отказаться от оказания очередной «помощи», ее голова в медицинской косынке символично закрывает последнее слово лозунга - «жизнь». Тем самым, в постблокадном городе фронтовичке достается роль палача, отнимающего жизнь у тех, которые, согласно послевоенной пропаганде, вернули ее советскому народу. Эвтаназию Ия старается исполнить гуманно, с неким подобием комфорта ${ }^{37}$. В данной связи примечательно имя героини, своей дополнительной семантикой («и я тоже»38) отсылающей к незавидной участи всех фронтовичек. Вынесенное же в название фильма прозвище Ии призвано подчеркнуть не только высокий рост неуклюжей девушки, но и обозначить общую угловатость и отчужденность от послевоенной реальности всех женщин, переживших фронтовой опыт ${ }^{39}$.

Маша, как и тысячи других советских женщин, добровольцем ушла на фронт и была зенитчицей ${ }^{40}$. В Ленинград она возвращается опьяненной победой героиней с неистовым желанием жить. Однако постблокадный город не спешит встречать ее как героиню-освободительницу. Вожделенная мирная жизнь оборачивается бескомпромиссной борьбой за право на счастье и незапятнанную репутацию ${ }^{41}$. Со стороны горожан Маша то и дело натыкается на пренебрежительное к себе отношение. Парень, сопровождающий Сашу в поездке по ночному городу, высокомерно трактует девушку в военной форме как легкодоступный товар: «О, фронтовая. Смотри, такие даже за еду готовы. Штаны расстегни, она дальше сама все сделает... Водить в кино не надо» (27:24-27:31). Начальник отделения военного госпиталя уже при первой встрече с трудом скрывает свою неприязнь к ехидной фронтовичке, что находит отражение в его сухом

37 После введения смертельной инъекции парализованному Степану, Ия помогает ему выкурить последнюю папиросу.

${ }^{38}$ Н. Карцев, Пустота..., с. 190.

39 А. Исрапилов, Рецензия на фильм..., https://www.film.ru/articles/recenziya-na-film-dylda (11.05.2021).

${ }^{40}$ Отследить историю фронтовой судьбы Маши не представляется возможным. Более того, имеющиеся скупые данные откровенно противоречат друг другу. Начальнику отделения военного госпиталя фронтовичка сообщает о том, что она вместе с Ией воевала в зенитных войсках; матери жениха Маша признается в том, что была походно-полевой женой. Вероятнее всего, в обоих сведениях есть доля истины.

${ }^{41}$ См.: Н. Ромодановская, Кантемир Балагов: «Я готовлюсь к негативным отзывам «Кинотавра» на «Тесноту», https://www.proficinema.ru/interviews/detail.php?ID=222400 (11.05.2021). 
расспросе, походящем на допрос. По возвращению в Ленинград значительно понижается социальный статус Маши: из доблестной зенитчицы она мгновенно деклассируется до уровня рядовой санитарки. Но с наибольшим сопротивлением молодая фронтовичка сталкивается со стороны женщин тыла в лице матери Саши, Любовь Петровны (Ксения Кутепова). В диалоге двух женщин, похожем на изощренный поединок, сталкиваются два женских мира: мир фронта, в котором превалируют мужчины (Маша), и мир тыла, в котором преобладают женщины (Любовь Петровна). Несмотря на то, что оба мира внесли вклад в победу во Второй мировой войне, между ними существует непреодолимая стена отчуждения, выстроенная из-за неосведомленности и, что еще важнее, нежелания знать друг о друге правду. Вернувшаяся фронтовичка сразу же оказывается под подозрением у привилегированной женщины, наслышанной о выполнении девушками «вспомогательных функций в тыловых подразделениях» (1:55:25-1:55:29). Для высокомерной хозяйки просторного особняка военное участие Маши могло ограничиваться лишь статусом походно-полевой жены. Осознав призрачность надежды быть принятой в семью жениха, девушка, хорошо усвоив уроки фронта, принимает вызов матери Саши, одновременно направив весь огонь сформировавшихся предубеждений на себя и стараясь посильнее ранить самолюбие номенклатурной дамы ${ }^{42}$ :

МАША: Я умела зарабатывать два года одним местом на хлеб, новые сапоги, на отпуск... Вернулась невредимой. Вы бы точно долго не протянули. ЛЮБОВЬ ПЕТРОВНА: ЭТо почему?

МАША: С вами бы никто не пошел. Вы бы собой даже на сто грамм хлеба не заработали. (1:57:30-1:58:04)

Ожесточенное сопротивление Маши сложившимся в тылу и перекочевавшим в послевоенный период предубеждениям обречено на поражение, поскольку укоренившемуся общественному мнению эффективно противодействовать чрезвычайно сложно, а основательно подорванное здоровье фронтовички не вселяет уверенности в то, что она сможет прожить долгую жизнь.

${ }^{42}$ См.: Н. Карцев, Пустота..., с. 188-189. 


\section{ЗАКЛЮЧЕНИЕ}

Между парой Ия и Маша есть много общего с концепцией инь и ян. Во многом вынужденно выполняющей традиционные женские функции Ия (забота о Пашке, фертильность, лучшая приспособленность к послевоенным будням) противостоит мужественная, рано повзрослевшая Маша, утратившая на фронте физическую способность стать матерью. Интроверту Ие привычно подчиняться, по инерции оставаться от кого-то зависимой. Активные действия для инфантильной девушки несвойственны. Экстраверт Маша, напротив, привыкла самостоятельно принимать решения, действовать, руководить и манипулировать окружающими. У молчаливой Ии мягкий характер; она готова пожертвовать собой ради близкого человека. Однако сквозь присущую ей покорность, порой может прорваться безудержная страсть, эгоистичный расчет и недюжинная физическая сила. В свою очередь, жесткая (а временами и жестокая), энергичная, шумная эгоистка Маша готова иногда пойти на уступки и на коленях просить Ию остаться с ней. Существенным отличием героинь фильма Дьлда от инь и ян являются цвета. Цвет Ии (вариация инь) - зеленый означающий плодородие, мирную жизнь, надежду. Цвет Маши (вариация ян) - красный, периодически переходящий в охру, знаменует собой смерть, войну, кровь, ржавчину жизни. Противоположные цвета, как у инь и ян, им также присущи. Безусловно две полярные оппозиции - высокая Ия и в сравнении с ней маленькая Маша - общим фронтовым опытом, физическими и психическими травмами припаяны друг к другу, вместе не достигают гармонии (создание семьи и обретение места в послевоенной эпохе), а «неустойчивая иерархия и переменная субординация» 43 не предусматривает в их отношениях равенства. Четкая граница между контуженной Ией и бесплодной Машей отсутствует, позволяя тем самым агрессивному красному без труда одержать верх над робко проступающим зеленым - в финале фильма Ия оказывается в красном свитере (подарок Маши), в то время как сама Маша одета в чужое зеленое платье усеянном красными цветами. Война отняла их юность, убила любовь, сделала физическими и психическими инвалидами, въелась в лица, жестикуляцию и гардероб,

43 А. Исрапилов, Рецензия на фильм..., https://www.film.ru/articles/recenziya-na-film-dylda (11.05.2021). 
а смерть продолжает их преследовать и в постблокадном городе. Запутанные отношения двух фронтовичек-ровесниц, вбирающие в себя женскую обездоленность, взаимную потребность, одиночество, насилие, дружбу и некое подобие семьи, токсичны и едва ли предусматривают совместное счастливое будущее. Даже осознавая это им не хватает сил, чтобы расстаться. В некоторой степени военные действия для зенитчиц были проще и понятнее: там надо было выживать, а враг, в лице немецких захватчиков, был общим. Мирные же будни подчас оказываются гораздо сложнее: смысл дальнейшей жизни молодые фронтовички еще только обретают и заставляют себя в него уверовать, как в чудо (общий послевоенный ребенок как исцеление от травм войны), а неприятелем могут оказаться «свои» (показательный пример - Любовь Петровна). Сумеет ли послевоенный ребенок в тяжело травмированном Ленинграде зарубцевать их глубокие, непрерывно саднящиеся раны и тем самым вернуть двум сиротливым девушкам иссякшие жизненные силы? Этот вопрос остается открытым.

\section{REFERENCES}

Aguilar, Carlos. "War Is a Source of Human Nature": Kantemir Balagov on His Women-Centered Period Two-Hander, Beanpole, <https://filmmakermagazine.com/109227-war-is-a-source-of-human-nature-kantemir-balagov-on-hiswomen-centered-period-two-hander-beanpole/\#.Xq_NH5ngo2x $>$.

Aleksiyevich, Svetlana. U voyny ne zhenskoye litso. Moskva: Vremya, 2019 [Алексиевич, Светлана. У войны не женское лицо. Москва: Время, 2019].

Artamonov, Aleksey. Kantemir Balagov: „Nado vzyat' zritelya za shkirku i ne otpuskat' yego" [Артамонов, Алексей. Кантемир Балагов: «Надо взять зрителя за шкирку и не отпускать его»] <https://seance.ru/articles/dyldabalagov-interview/>.

Chu, Hau. Oscar-shortlisted 'Beanpole' is a solid, if bleak, sophomore effort by Kantemir Balagov, <https://www.washingtonpost.com/goingoutguide/movies/oscar-shortlisted-beanpole-is-a-solid-if-bleak-sophomore-effort-by-kantemir-balagov/2020/02/18/2c398efe-4ea5-11ea-bf44-f5043eb3918a_story. html?arc404=true $>$.

Chugunkina, Veronika. Kak samorodok iz Nal'chika Kantemir Balagov stal nadezhdoy rossiyskogo kinematografa [Чугункина, Вероника. Как самородок из Нальчика КантемирБалаговсталнадеждойроссийскогокинематографа] $<$ https://ru.hellomagazine.com/zvezdy/intervyu-i-video/31961-kak-samorodok-iz-nalchika-kantemir-balagov-stal-nadezhdoy-rossiyskogo-kinematografa. html>.

Dolin, Anton. «Dylda» Kantemira Balagova: sil'naya istoriya lyubvi v posleblokadnom Leningrade [Долин, Антон. «Дылда» Кантемира Балагова: сильная 


\section{ТИПОЛОГИЯ ОБРАЗОВ ФРОНТОВИЧЕК...}

история любви в послеблокадном Ленинграде] < https://meduza.io/featu-

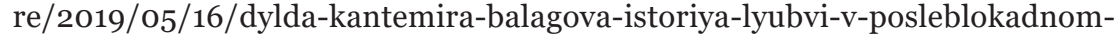
leningrade $>$.

Dolin, Anton. "My ne imeyem prava pokazyvat' svoikh geroyev slabymi, my dolzhny uvazhat' ikh lichnost'». Rezhisser Kantemir Balagov - o fil'me "Dylda», dvazhdy nagrazhdennom $v$ Kannakh [Долин, Антон. «Мы не имеем права показывать своих героев слабыми, мы должны уважать их личность». Режиссер Кантемир Балагов - о фильме «Дылда», дважды награжденном в Каннах] <https://meduza.io/feature/2019/o6/19/my-ne-imeem-pravapokazyvat-svoih-geroev-slabymi-my-dolzhny-uvazhat-ih-lichnost $>$.

Dombrovskaya, Inga. "Traurnoye sosedstvo s zhizn'yu» - Kantemir Balagov o svoyem fil'me «Dylda» [Домбровская, Инга. «Траурное соседство с жизнью» - Кантемир Балагов о своем фильме "Дылда»] <http://www. rfi.fr/ru/kultura/20190516-kantemir-balagov-cheloveku-nuzhen-chelovek>.

Israpilov, Alikhan. Retsenziya na fil'm «Dylda»: Leningrad, otkrytyy gorod [Исрапилов, Алихан. Рецензия на фильм «Дылда»: Ленинград, открытый город] <https://www.film.ru/articles/recenziya-na-film-dylda>.

Ivanov, Anton. Kantemir Balagov: "Ya ne osobennyy, mne prosto poka vezet, vot i vse» [Иванов, Антон. Кантемир Балагов: "Я не особенный, мне просто пока везет, вот и все»] <https://bazaar.ru/bazaar-art/kino/kantemir-balagov-ya-ne-osobennyy-mne-prosto-poka-vezet-vot-i-vse/>.

Kartsev, Nikita. "Pustota. «Dylda», rezhisser Kantemir Balagov." Iskusstvo kino 2019, no. 7/8 [Карцев, Никита. "Пустота. «Дылда», режиссер Кантемир Балагов.” Искусство кино 2019, no. 7/8].

Kiang, Jessica. Film Review: 'Beanpole', <https://variety.com/2019/film/marketsfestivals/beanpole-review-1203215728/>.

Lévesque, François. «Une grande fille»: les amitiés contraires, <https://www.ledevoir.com/culture/cinema/573381/une-grande-fille-les-amities-contraires $>$.

Polok, Dominika. Wojna psychologiczna (Wysoka dziewczyna), <http://artpapier. com/index.php?page $=$ artykul\&wydanie $=381 \&$ artykul $=7588>$.

Romodanovskaya, Nina. Kantemir Balagov: «Ya gotovlyus' $k$ negativnym otzyvam «Kinotavra» na «Tesnotu» [Ромодановская, Нина. Кантемир Балагов: «Я готовлюсъ $\kappa$ негативным отзывам «Кинотавра» на «Тесноту»] $<$ https://www.proficinema.ru/interviews/detail.php?ID=222400>.

Smolina, Yelena. «Dylda» Kantemira Balagova $v$ «Osobom vzglyade» Kannskogo festivalya [Смолина, Елена. «Дылда» Кантемира Балагова в «Особом взгляде» Каннского фестиваля] <https://www.gq.ru/entertainment/dylda-review>.

Sukiasyan, Samvel, Soldatkin, Viktor, Snedkov, Yevgeniy, Tadevosyan, Margarita, Kosenko, Viktor. "Boyevoye posttravmaticheskoye stressovoye rasstroystvo: evolyutsiya ponyatiya ot «sindroma razdrazhennogo serdtsa» do "psikhogenno-organicheskogo rasstroystva»." Zhurnal nevrologii i psikhiatrii im. S.S. Korsakova 2019, vol. 119, no. 6 [Сукиасян, Самвел, Солдаткин, Виктор, Снедков, Евгений, Тадевосян, Маргарита, Косенко, Виктор. "Боевое посттравматическое стрессовое расстройство: эволюция понятия от «синдрома раздраженного сердца» до «психогенно-органического расстройства»." Журнал неврологии и психиатрии им. С.С. Корсакова 2019, т. 119, № 6].

Superanskaya, Aleksandra. Sovremennyy slovar' lichnykh imen: Sravneniye. Proiskhozhdeniye. Napisaniye. Moskva: Ayris-press, 2005 [Суперанская, 
Александра. Современный словарь личных имен: Сравнение. Происхождение. Написание. Москва: Айрис-пресс, 2005].

Tangcay, Jazz. How Research Prompted 'Beanpole' Director Kantemir Balagov to Shoot in Color, <https://variety.com/2020/artisans/awards/beanpole-kantemir-balagov-1203456481/>.

Taylor, Rodney Leon, Howard Y.F. Choy, "Yin/yang." Taylor, Rodney Leon, Howard Y.F. Choy. The Illustrated Encyclopedia of Confucianism. Vol. 2. New York: The Rosen Publishing Group, Inc., 2005. 719-722.

Yeliseyeva, Marina. Sila slabykh: zhenshchiny na Velikoy Otechestvennoy voyne [Елисеева, Марина. Сила слабых: женщины на Великой Отечественной войне] <https://army.ric.mil.ru/Stati/item/252043/>. 